\title{
The Paradox of the Valentine Thomas Affair: English Diplomacy, Royal Correspondence and the Elizabethan Succession
}

\author{
Elizabeth Tunstall
}

\begin{abstract}
In 1598 the Catholic Valentine Thomas was apprehended near Morpeth in northern England. Thomas's confession accused King James VI of Scotland of encouraging him to murder Queen Elizabeth I of England. Rumours of Thomas's confession reached Scotland, transforming it into a matter of Anglo-Scottish diplomacy. This article will focus on the English political context as intensive diplomatic exchanges passed between ambassadors and through the royal correspondence in the search for a resolution. The Valentine Thomas affair was a paradox, for while the plot was minor, its connection to the Elizabethan succession debate turned it into a matter of diplomatic importance.
\end{abstract}

Valentine Thomas was a nobody in late sixteenth-century England. Yet, despite this, he was at the heart of an ongoing problem of Anglo-Scottish diplomacy, one which also featured prominently within the royal correspondence exchanged between Queen Elizabeth I of England and King James VI of Scotland. The Valentine Thomas affair is almost a footnote in the history of Elizabeth's lengthy reign, often not even being discussed at all in the scholarship. While this is understandable in light of the many momentous occurrences of that reign, it does not make the matter unimportant, particularly in light of its continuation over a period of five years. The Valentine Thomas affair was significant only because of the potential implications of Thomas's confessions on the as yet unsettled succession to the English throne. Elizabeth and James perceived the situation and how to manage it differently, causing an ongoing diplomatic conundrumparticularly for the English - which shall be explored. While James's responses to the Valentine Thomas affair will be considered, this article is primarily focused upon the English political context, within which the likely succession of the King of Scots was seen with unease by many of the political class. This article will explore the Valentine Thomas affair fully for the first time and consider how the capture of a suspected horse thief in the north of England could impact so significantly upon Anglo-Scottish diplomacy and the royal correspondence, while being approached in dramatically different manners by each party.

The Valentine Thomas affair is generally summarized in the scholarship as follows. In 1598 Valentine Thomas, a suspected horse thief and Catholic, was 
captured near Morpeth in Northumberland, England. ${ }^{1}$ When questioned, Thomas confessed to plotting against Elizabeth. Furthermore, he alleged that he had met James and that the King of Scots had agreed to Thomas's proposed assassination of Elizabeth. ${ }^{2}$ When told of the allegation Elizabeth kept the situation secret and did not initially inform James. However, when James learned of the accusations, he became anxious about the implications of Thomas's confession for his chance to succeed Elizabeth. ${ }^{3}$ Elizabeth and her Privy Council sought to calm James, yet he continued to agitate for adequate satisfaction in the matter. He demanded that his name be removed from Thomas's trial documents and for a public declaration of his innocence. However, his contradictory demands could not be fulfilled, as by publicly declaring his innocence the entire situation would have become public rather than remain secret. Instead, Elizabeth had Thomas placed without trial in the Tower, where he remained imprisoned until after her death. ${ }^{4}$ The broad outlines of the Valentine Thomas affair therefore appear straightforward: a conspiring assassin was captured, and confessed with an outrageous tale that was disbelieved in England. Nevertheless, this affair became an ongoing concern for AngloScottish diplomacy and also an important thread in the correspondence exchanged between Elizabeth and James in the later years of her reign. It is a topic that needs further consideration than has previously been the case in the scholarship of the later years of Elizabeth's reign, especially regarding its potential implications for the English succession.

The Valentine Thomas affair has only occasionally been discussed within the scholarship relating to the Elizabethan succession or late sixteenth-century Anglo-Scottish diplomacy. When the topic is raised it is generally covered in the space of a single paragraph, a few pages, or on one occasion in a sole footnote of a much larger work. ${ }^{5}$ Susan Doran has written more on the affair than other scholars,

1 John Guy, Elizabeth: The Forgotten Years (New York: Viking, 2016), p. 365.

2 Maurice Lee Jr, Great Britain's Solomon: James VI and I in his Three Kingdoms (Urbana: University of Illinois Press, 1990), p. 82.

3 Susan Doran, 'Three Late-Elizabethan Succession Tracts', in The Struggle for the Succession in Late Elizabethan England: Politics, Polemics and Cultural Representations, ed. by Jean-Christophe Mayer (Montpellier: Institut de Recherche sur la Renaissance, 2004), pp. 91117 (p. 96).

4 Susan Doran, 'James VI and the English Succession', in James VI and I: Ideas, Authority and Government, ed. by Ralph Houlbrooke (Aldershot: Ashgate, 2006), pp. 25-42 (pp. 38-40); Susan Doran, 'Loving and Affectionate Cousins? The Relationship between Elizabeth I and James VI of Scotland 1586-1603', in Tudor England and its Neighbours, ed. by Susan Doran and Glenn Richardson (New York: Palgrave Macmillan, 2005), pp. 203-34 (p. 223).

5 Alexander Courtney, 'The Scottish King and the English Court: The Secret Correspondence of James VI, 1601-3', in Doubtful and Dangerous: The Question of Succession in Late Elizabethan England ed. by Susan Doran and Paulina Kewes (Manchester: Manchester University Press, 2014), pp. 134-51; Doran, 'Three Late-Elizabethan Succession Tracts'; Doran, 'Loving and Affectionate Cousins?'; Doran, 'James VI and the English Succession'; Susan Doran, Elizabeth I and her Circle (Oxford: Oxford University Press, 2015); Guy, Elizabeth; Lee, Great Britain's Solomon; Wallace T. MacCaffrey, Elizabeth I: War and Politics 1588-1603 (Princeton: Princeton University Press, 1992); Michael Questier, Dynastic Politics and the 
with it appearing in five of her works. ${ }^{6}$ According to Doran, while 'the matter was actually of very little consequence, it was to obsess James for several years because of his belief that it impinged on his right to the succession' . Across her works Doran has consistently argued that Elizabeth and her Privy Council saw the situation as being of little importance, as they disbelieved Thomas's accusations against James. However, James himself saw the matter differently and demanded contradictory means to deal with Thomas's accusation, means which would have been counterproductive in the English political context. For the most part, scholars who have touched upon the Valentine Thomas affair have considered the situation in a roughly similar way to Doran. Alexander Courtney, in his paragraph on the affair, stressed James's dissatisfaction with Elizabeth's treatment of Thomas, arguing that James did not feel she went far enough to clear his name from the implication of his involvement. ${ }^{8}$ Wallace T. MacCaffrey also dwelt upon James's strong reaction to Thomas's accusations, writing that 'James, initially troubled that the matter should have been concealed, soon became almost hysterical in his anxiety over the affair'. ${ }^{9}$ Similarly, Maurice Lee Jr, in his brief consideration of the Valentine Thomas affair, argued that while the incident was significant for James, as it provoked a level of anxiety over his chances to succeed Elizabeth, James's requests for how the matter should be managed would be counterproductive to his aims, as they would likely 'stir English memories and prejudice English opinion' ${ }^{10}$ That James's demands were likely to risk his succession through prejudicing the English political class against him was key to the English response, as will be discussed below.

While the Valentine Thomas affair has generally been considered in a more or less uniform way in contemporary scholarship, John Guy has raised a dissenting voice on the situation. In Guy's book Elizabeth: The Forgotten Years he argues that Elizabeth believed Valentine Thomas's accusations against James to be true and that she thought James had been involved in Thomas's plot to assassinate her. ${ }^{11}$ As a result of this belief 'she meant to keep Thomas on ice in the Tower as an insurance policy against James until she died' to prevent James taking actions contrary to English diplomatic objectives. ${ }^{12}$ Guy's position on the affair has some similarities to a point raised in 1940 by Helen Georgia Stafford that in Thomas

British Reformations, 1558-1630 (Oxford: Oxford University Press, 2019); Helen Georgia Stafford, James VI of Scotland and the Throne of England (New York: Appleton-Century, 1940).

6 Susan Doran, 'Revenge her Foul and Most Unnatural Murder? The Impact of Mary Stuart's Execution on Anglo-Scottish Relations', History, 85 (2000), 589-612; Doran, 'Three Late-Elizabethan Succession Tracts'; Doran, 'Loving and Affectionate Cousins?'; Doran, 'James VI and the English Succession'; Doran, Elizabeth I and her Circle.

7 Doran, 'Loving and Affectionate Cousins?', p. 221.

8 Courtney, 'The Scottish King and the English Court', p. 136.

9 MacCaffrey, Elizabeth I, p. 323.

10 Lee, Great Britain's Solomon, p. 82.

11 Guy, Elizabeth, pp. 365-66.

12 Guy, Elizabeth, p. 366. 
Elizabeth 'had a weapon to restrain James'. ${ }^{13}$ However, Stafford's full argument was that James had overreacted, and that to the Elizabeth and her government Thomas's accusations were 'rather obviously the invention of a half-mad criminal who hoped to obtain his freedom by making accusations against important persons' ${ }^{14}$ Guy's unorthodox view of the affair is potentially valid, but, as this article will demonstrate, unlikely. Elizabeth's actions regarding Thomas could have been seen by James and his supporters as her maintaining an 'insurance policy', to use Guy's terminology, against James regarding the succession. However, from within the English political context, should they take action as James demanded it would likely have caused the very damage to his potential succession that he feared. The reality of the affair, and its significance, is to be found here in its political paradox, an almost Schrödinger's cat of the succession. While Thomas's plot itself posed no real risk to Elizabeth's life and was ultimately insignificant, the affair as a whole was highly significant in the mind of James and therefore had the potential to impact upon the succession. This article will explore this paradox of viewpoints concerning the Valentine Thomas affair, where both Elizabeth and James had wildly different understandings of the matter, understandings that were both fundamentally driven by the issue of the succession, which ultimately functioned within the English political context.

\section{The Diplomacy of the Valentine Thomas Affair, 1598-1599}

The first known record of the Valentine Thomas affair did not actually involve the man himself. Rather, it occurred with the capture of Robert Crawforth of Wittsome, a Scotsman, on the English side of the Borders. Following his capture, he was examined by the deputy warden of England's Middle Marches and his confession triggered what would become the affair. Crawforth stated that he had met Valentine Thomas, then going by the name Thomas Anderson, 'upon wenesday before St Lukes day' in 1597. ${ }^{15}$ Together with a third man, John Brotherstones of Tranent in Scotland, they had travelled and stolen horses. During their travels they had stopped in Edinburgh, and while there they

went to hallyroode house being the $\mathrm{k}$ [ing]s pallace, after day light to the house of Mr John Steward keeper of the kings chamber doore who brought him the sayd Valentine presently to secrett conference w[it]h the king so nightly for the space of $\mathrm{v}$ or vi nights together to confer privately $\mathrm{w}[\mathrm{it}] \mathrm{h}$ the kinge. ${ }^{16}$

According to Crawforth, during these meetings Thomas discussed how James could claim England. After returning to England Crawforth and Thomas went their separate ways, shortly after which Crawforth was captured and he agreed to help

13 Stafford, James VI of Scotland and the Throne of England, p. 195.

14 Stafford, James VI of Scotland and the Throne of England, pp. 193-95.

15 Examination of Robert Crawforth, 2 March 1598, Kew, The National Archives (hereafter TNA), SP 59/37, fol. 16.

16 Examination of Robert Crawforth, 2 March 1598, TNA, SP 59/37, fol. 18. 
the English to apprehend Thomas. ${ }^{17}$ With Crawforth's assistance Edward Gray, the deputy warden handling the situation, apprehended Thomas as he passed through Morpeth, after which Thomas was transferred to London. ${ }^{18}$

Once in London, proceedings against Thomas appeared to move unusually slowly. Dudley Carleton wrote to John Chamberlain that 'The arainement of Valentine Thomas (w[hi]ch you cheefly putt me in remembrance to write of) is still putt of, and so will be till the iudges be met' ${ }^{19}$ However, in the secret spaces of Elizabeth's government, the affair had long since taken on a life of its own, as during questioning Thomas had made a confession, one which triggered this unusual episode in Anglo-Scottish diplomacy. Thomas's confession, which was recorded more officially at a later date, stated that

Valyntine Thomas otherwise called Thomas Alderson or Anderson confesseth that his accesse to the king of scottes was principally procured by one John Steward of the Butty, who keepeth the kinges doore, and that he repared to the King at sondrie tymes and in sondry places..$^{20}$

His confession continued to state that James had ordered Thomas to 'take an ocasion to deliuer a peticion to the Queene in manner as you shall thinke good, and so may you come neare to stabbe her'. ${ }^{21}$ Thomas's accusations were considered to be untrue. However, even false accusations could cause great harm, so it was determined that the affair would be kept secret and that James would not be informed.

Elizabeth and her government's desire that Thomas's accusations remain secret proved to be impossible, as rumours of Thomas and his accusations travelled north to Scotland. While there is no direct evidence of the English government's decision to keep the accusations secret, the first traces of the affair in the AngloScottish diplomatic exchange first appeared in a dispatch from Scotland rather than a message from London, which is highly suggestive of the English government's intentions. Additionally, matters of significant sensitivity, such as Thomas's accusations, were not recorded in the English Privy Council registers, leaving us to piece together Privy Council's thinking from the passage of the diplomatic exchange. ${ }^{22}$ George Nicolson, Elizabeth's agent in Scotland wrote to William Cecil, Lord Burghley, on 11 May 1598. In a postscript to this letter, Nicolson reported that James was concerned with the accusations of Thomas, stating it was

17 Examination of Robert Crawforth, 2 March 1598, TNA, SP 59/37, fol. 18.

18 Edward Gray to Lord Burghley, 4 March 1598, The Cecil Papers (hereafter CP), $49 / 51$.

19 Dudley Carleton to John Chamberlain, 1 August 1598, TNA, SP 12/268, fol. 34.

20 Confessions of Valentyne Thomas, 20 December 1598, TNA, SP 52/63, fol. 81.

21 Confessions of Valentyne Thomas, 20 December 1598, TNA, SP 52/63, fol. 81.

22 Michael Barraclough Pulman, The Elizabethan Privy Council in the Fifteen-Seventies (Berkeley: University of California Press, 1971), p. 168; David J. Crankshaw, 'The Tudor Privy Council, c. 1540-1603' (Cengage Learning EMEA, 2009) < http://gale.cengage.co.uk/statepapers-online-15091714/part-ii.aspx $>$. 
'A matter w[hi]ch the $\mathrm{K}$ [ing] denyes ever to have once thought on, and from w[hi] ch he will ever be clear and unwilling [...] to be so acompted as an intender of such vile murther'. ${ }^{23}$ In June the issue was followed up by James Hudson, who met with David Foulis, a man who had previously undertaken embassies to London for James. ${ }^{24}$ Foulis reported that before the affair James had

never aprehendid matter (whatsoever) in so high a degre, neither ever did or wil seek redress with greater earnestness than he wil do in this. For he saeth it cuts hime of frome al his hopes \& possibilities to come. It bereaves hime of his prinsly reputasion w[it]h all princes. It burieth his honor in the grave of oblivion \& blemisheth his lyne \& posteretie for ever. ${ }^{25}$

From the reports from Scotland it became clear that James had taken the situation incredibly seriously and maintaining silence would no longer be possible. Therefore, it was determined that formal instructions were to be sent to the English resident in Scotland to seek an audience with James in order to 'arquainte him that one Valentyne Thomas, a subicte of ours, lewdelye disposed and longe accused for manye notorious crymes' ${ }^{26}$ Furthermore, Elizabeth determined that the matter had reached a point that required her personal involvement, prompting her to write to James herself.

The exchange of correspondence was the main means of communication during the sixteenth century, when distance made face-to-face discussion impossible. Such an exchange of letters was not a simple procedure, as protocol and custom exerted influence upon all aspects of the process, from the decision to write it in one's own hand rather than delegate the task to a secretary to the rhetorical framing of the message and the spacing of the composition upon the paper. ${ }^{27}$ Elizabeth and James had a firm understanding of these processes and engaged in a significant correspondence exchange, of which two hundred and sixty letters have survived, with up to fifty-five per cent of the letters written in their own hands. The correspondence officially began in 1572 when James was six years old, but only fully developed from the late 1570s, and lasted until Elizabeth's death in 1603. ${ }^{28}$ Through this correspondence Elizabeth and James engaged in a

23 George Nicolson to Lord Burghley, 11 May 1598, TNA, SP 52/62, fol. 29.

24 Fiona Pogson, 'Foulis, Sir David, First Baronet (d. 1642)', in Oxford Dictionary of National Biography (2004), <https://www.oxforddnb.com>.

25 James Hudson to Queen Elizabeth, [c. June 1598], TNA, SP 52/62, fol. 38.

26 Instructions for One to be Sent into Scotland, 1 July 1598, TNA, SP 52/62, fol. 46.

27 James Daybell, The Material Letter in Early Modern England: Manuscript Letters and the Culture and Practices of Letter-Writing, 1512-1635 (New York: Palgrave Macmillan, 2012), pp. 10-11.

28 Rayne Allinson, 'The Letters of Queen Elizabeth I and King James VI: Kingship, Kinship and the Politics of Counsel' (unpublished master's thesis, University of Melbourne, 2006), p. 19; Rayne Allinson, "“These Latter Days of the World": The Correspondence of Elizabeth I and King James VI, 1590-1603', Early Modern Literary Studies, Special Issue, 16 (2007), 2.1-27 (3) <http://purl.oclc.org/emls/si-16/allilatt.htm>. 
more personal level of diplomatic exchange, built upon their family relationship and Elizabeth's role as James's godmother. ${ }^{29}$ The correspondence had proved vital during the period before and after Mary Stuart's execution in 1587, when both monarchs made use of it to negotiate the treacherous diplomatic circumstances of the situation. ${ }^{30}$ With Thomas's accusations reaching James in Scotland, though thoroughly disbelieved in the English court, it was essential that his mind was put at ease before a significant diplomatic situation arose, and as such Elizabeth chose to use their shared correspondence.

On 1 July 1598 Elizabeth wrote a short letter to James. It had been a few months since her last and she began by stating he should 'Suppose not that my silence hathe any other Root then hating to make an argument of my writinge to you' ${ }^{31}$ The evidence indicates that Elizabeth had not wished to raise the issue of Thomas at all, in either her letters or through other avenues of diplomacy. Nevertheless, the rumours of Thomas's accusation had forced Elizabeth's hand, requiring her to address the situation personally regardless of her preferences, 'being most desirous that no mention might once be made of so villainous an Act, specially that might but in worde touche a sacred person'. ${ }^{32}$ Thomas was not named in Elizabeth's letter, nor did she detail the accusations he had made against James, instead choosing to entrust those details to her ambassador to relay. Her letter was to serve a different purpose, which was to state her personal disbelief in the accusations, 'And charge you in Gods name to belyeve, that I am not of so viperous a nature to suppose or haue thereof a thought against you'. ${ }^{33}$ Elizabeth's first letter may have been brief but it was strong in both tone and her firm disbelief in James's involvement in any plot devised by Thomas against her, or indeed the seriousness of the plot itself. However, as the royal correspondence reveals, Elizabeth's position on the matter was not shared by James.

Within a month of Elizabeth's letter, 30 July, James responded in a short but firmly worded letter written in his own hand. James opened his letter by stating his absolute innocence in the affair that Thomas had confessed, 'But, in truth, I beare so little regard to so vyle and treacherous lyes proceeding from so base a fountaine as I, though my only innocence, should have force enough to beare me through the foggie miste of suche groundless calumnies'. ${ }^{34}$ Indeed, James's statements went further than simply asserting his innocence, as he bluntly referred to the accusations levelled against him by Thomas as 'shameles fictions', falsities that

29 Allinson, 'These Latter Days of the World", 8.

30 Elizabeth Tunstall, 'Of Honour and Innocence: Royal Correspondence and the Execution of Mary, Queen of Scots', Melbourne Historical Journal, 47 (2019/20), 57-72.

31 Elizabeth to James, 1 July 1598, TNA, SP 52/62, fol. 44.

32 Elizabeth to James, 1 July 1598, TNA, SP 52/62, fol. 44.

33 Elizabeth to James, 1 July 1598, TNA, SP 52/62, fol. 44.

34 James to Elizabeth, 30 July 1598, British Library (hereafter BL), Cotton MS Titus C VII, fol. 19. 
were intended to slander his name and honour. ${ }^{35}$ While denying any involvement, or even that he had heard of Thomas's plans before his capture, James began a significant diplomatic effort to manage the affair in what he considered the appropriate manner. In his letter to Elizabeth, he wrote:

My suit only is that untile ye heare farther from me (which shall be with all diligence) ye would favour me so farre as to delay the Fellows execution if he be yet alive to the effect that by some honourable meanes, wherein I am to deale with you, my undeserved slander may be removed from the mindes of all men. ${ }^{36}$

It is clear from James's first letter concerning the affair that he considered the situation as more significant than Elizabeth did, and that he would be pursuing the matter further through various diplomatic means.

Following the dispatch of his letter James decided that his correspondence with Elizabeth would not be sufficient for a concern of such weight, and that an embassy to the English court would also be necessary. James wrote again to Elizabeth in August to inform her of his decision and to name David Foulis as his servant in this affair, "quhomby ye shall be informed quhat I craue for clearing of my honoure anent these slanders quhiche that base uillaine hach raised upon me quhairin I doubte not but youre honour \& loue towardis me will moue you not to see me innocentlie wrongid'. ${ }^{37}$ While this letter is primarily focused on preparing the ground for the Scottish embassy, James also sought to firmly protest his innocence in the whole affair again. 'For on my honoure I wolde wishe that all the direct or indirect dealing that euer I hadde that might concerne your personne or state were in a booke laide oppen before you, $\&$ then ye woulde see that no subiect of england hath kept him self cleerer of any guilte against you then I have done euer since I was borne' ${ }^{38}$ James argued strenuously in his letters to Elizabeth that he was not involved in Thomas's plots, nor had ever undertaken actions that could be considered a threat to her life. He also appealed for her to prove that she did not believe Thomas, an appeal that is rather peculiar considering Elizabeth's only letter to date on the affair had firmly stated her belief in his innocence. James's determination to establish his innocence and remove any possibility for doubt led to Foulis's embassy and the continued presence of Valentine Thomas in the royal correspondence.

While James had sent Foulis to England to manage the affair he did not leave it entirely in his ambassador's hands, and continued to correspond with Elizabeth on the situation. From James's letter dated 26 September, it is clear that Elizabeth and her government had maintained their initial belief in James's innocence in the affair, which they relayed to his ambassador. James wrote to Elizabeth,

35 James to Elizabeth, 30 July 1598, BL, Cotton MS Titus C VII, fol. 19.

36 James to Elizabeth, 30 July 1598, BL, Cotton MS Titus C VII, fol. 19.

37 James to Elizabeth, [August 1598], CP, 133/138.

38 James to Elizabeth, [August 1598], CP, 133/138.

Parergon 38.1 (2021) 
having found by letters from my servant Fowlis the continuance of your honourable and kind conceit of my innocencie in this vile \& untrue calumnyie forged upon me by Valentyne Thomas, I could do no lesse than by these lynes to witness my thankful mynd acknowledging my debt heaped herein, w[hi]ch by all honourable \& loving offices I am obliged to repaye; assuring my self that you will continue in the same loving course by seeing my name cleared herein and the ground of those calumnies clearly tryed. ${ }^{39}$

James's anxiousness that his name be completely cleared of any implication of complicity in Thomas's plot is a common thread in his letters to Elizabeth. However, his assessment of the seriousness of Thomas's accusations was not shared by either his fellow monarch or her government. Indeed, they approached the whole matter as a small issue that had been blown out of all proportion by James, though they sought to satisfy him as best they could without giving Thomas and his accusations any further significance.

David Foulis travelled to London to negotiate the settlement of the Valentine Thomas affair to James's satisfaction. James Elphinstone, the Scottish Secretary of State, wrote to Foulis outlining the tasks for his embassy to England. Foulis's instructions stated that the King would be satisfied with nothing less than a 'publik declaration of his innocencie', and additionally that he was 'rased out of the said records' concerning Thomas's confession. ${ }^{40}$ Foulis, in pursuit of his instructions, wrote to Sir Robert Cecil, the English Secretary of State. He outlined three possible ways with which James might be satisfied and his name cleared of the affair, listed from his most favoured solution to the least favourable but nevertheless satisfactory. The first of these was Elphinstone's declaration,

an act of his iustification upon the scandal made by Val: Tho: against his $\mathrm{ma}[\mathrm{jes}] \mathrm{tie}$, to be presently sett down in suche honourable and substantiall termes as appertaines, to be printed and published throughout all the boroughs \& towns in England, containing the invaliditie and falsitie of the said Val:'s confessions and slanderous speeches. ${ }^{41}$

Included with Foulis's letter to Cecil was a model of the public act that James desired..$^{42}$ If this highly public approach was not taken, Foulis recommended secrecy be adopted, and that any mention of James in documents relating to Thomas be 'rased and delyvered to me to be gevin to his Ma[jes]tie'. ${ }^{43}$ Finally, if the first two options did not suit the English then Thomas could be tried in the Star Chamber with his public accusations against James cancelled. ${ }^{44}$ The requests James had Foulis deliver were somewhat contradictory in nature, seeking a public

39 James to Elizabeth, 26 September 1598, TNA, SP 52/63, fol. 16.

40 James Elphinstone to [David Foulis], 26 September 1598, TNA SP 52/63, fol. 17.

41 David Foulis to Sir Robert Cecil, 9 October 1598, TNA SP 52/63, fol. 30.

42 David Foulis to Sir Robert Cecil, 9 October 1598, TNA SP 52/63, fol. 31.

43 David Foulis to Sir Robert Cecil, 9 October 1598, TNA SP 52/63, fol. 30.

44

David Foulis to Sir Robert Cecil, 9 October 1598, TNA SP 52/63, fol. 30. 
declaration of James's innocence while also attempting to suppress any record that connected James to Valentine Thomas, a contradiction that was difficult for the English to satisfy.

With the Valentine Thomas affair now approaching five months the English decided upon settling the matter through three documents - a declaration, a proclamation, and a personal letter from Queen Elizabeth to the nervous Scottish king. The English solution to the affair was outlined in Cecil's letter to Nicolson in early November. Cecil stated that Thomas had only been indicted, as Elizabeth has stayed his arraignment, thus ensuring that there were no records of his accusation beyond his original examination, which was shown to Foulis. Additionally, a declaration was to be drawn up stating James's innocence in Thomas's plot, which was to be signed and sealed by Elizabeth. ${ }^{45}$ The declaration Cecil wrote of was drawn up and dated 20 December, and opened by stating:

Wheras one Valentyne Thomas otherwise called Thomas Anderson, a lewde caytife born our subiect, being apprehended on the Borders has delivered (w[it]hout torture, menace or $\mathrm{p}$ [er]suasion) diverse informacions of practices contryved between the King of Scottes, our good Brother, and him for the taking away of our lyfe: for w[hi] ch he was $\mathrm{p}[\mathrm{ro}] \mathrm{mised}$ great rewards by the King when it should be $\mathrm{p}$ [er]formed: forasmuch as it appeareth unto us that notw[it]hstanding such satisfaction as wee have given him by our former privat leters (wherein we have declared howe farre wee were from beleefe in any such accusation) $[\ldots] .{ }^{46}$

Elizabeth's belief in James's innocence and how little she had ever thought of the whole situation is firmly expressed within this declaration, asserting:

whereby we testifie that as wee have bene carefull (ever since his cradle) not only to $\mathrm{p}[\mathrm{re}]$ serve his estate from that danger in $\mathrm{w}[\mathrm{hi}] \mathrm{ch}$ it was like to fall but to conserve his own $\mathrm{p}$ [er]son in safety: so when we consider him to be a Christian prince of honor and religion (\& iudge him by the measure of our owne mynd towards him in all thinges) we do hereby $\mathrm{p}$ [ro]fess to all to whom these letters shall come that we do give no credit to such thinges as the said Valentyne Thomas hath affirmed against our good brother in any sort. ${ }^{47}$

Through the halting of proceedings against Thomas and the provision of the declaration, the English sought to satisfy James in a matter that they considered relatively insignificant, and for James's own sake best kept out of the public's consciousness. The final act as far as they were concerned was to be taken by Elizabeth herself in a letter to James.

45 Sir Robert Cecil to George Nicolson, 7 November 1598, TNA SP 52/52, fol. 227.

46 Declaration of Queen Elizabeth Concerning Valentyne Thomas, 20 December 1598, TNA, SP 52/63, fol. 82 .

47 Declaration of Queen Elizabeth Concerning Valentyne Thomas, 20 December 1598, TNA, SP 52/63, fol. 82 . 
Following her initial letter at the beginning of July, Elizabeth appears to have been content to leave the Valentine Thomas affair in the hands of diplomats as she did not consider it to be significant, and therefore did not write again on the issue until 26 December. Furthermore, Elizabeth's letter to Nicolson, roughly dated to the end of December that year, indicates that she thought that, in addition to being unimportant, the whole subject was distasteful: 'we will ende the discourse of this unpleasant subiect $\mathrm{w}[\mathrm{it}] \mathrm{h}$ this promise, that as we have beene content to spare this caytiffe for the Kynges sake only, so shall he not need to doubte' ${ }^{48}$ Regardless of her general opinion of the affair, Elizabeth wrote to James in an attempt to soothe his anxieties.

Unnaming therefore what it was, it may suffice that you nor other kings ever mett $w[i]$ th a better mynde nor a rarer intent, $w[$ hi] ch hath bene well as fulle uttered, by my signature to such a graunt as I suppose you might have asked of manie kings \& lackt such a furniture. But I forthinke it not, w[i]th a trust that in all other matters that may concerne my self or state we shall be rightlye aunswered with equall care and unfayned kindness. In this you shall strengthen yourself and render me my dewe. ${ }^{49}$

In this letter Elizabeth highlighted her long-standing care for James, and that other monarchs would not have been prepared to go to such lengths to satisfy him over the baseless accusations of a known criminal. It was her intention that through the issuing of the declaration and her personal letter of assurance that James would be content, yet this was not to be the case.

Early in 1599, following Foulis's return to Scotland, the problem of Valentine Thomas's confession continued to occupy the thoughts of James regardless of the English position on the subject. At the beginning of February Nicolson wrote to Cecil, asserting 'the King has again viewed and reviewed such things as Mr. David brought anent his acquittal of that matter of Valentyne Tho[mas's] slanders, and the more he views them the less contentment he finds' ${ }^{50}$ By the end of the month the stories of James's dissatisfaction with the affair returned to the diplomatic correspondence between England and Scotland, with Elphinstone writing to Cecil:

The King, his ma[jes]tie, being every way displeased with his servant Foulis at his return for he had exceeded the bounds of his credit in accepting such satisfaction in the matter of Valentyne Thomas as was no way agreeable to his ma[jes]ties honor nor his directions in that poynt, hath therefore commanded me to returne both the same to your handes. ${ }^{51}$

While England and Elizabeth may have considered the whole matter concluded, it is apparent that the affair was viewed differently in Scotland, and that it would fol. 33 .
Queen Elizabeth to George Nicolson, TNA, SP 52/52, fol. 233.

Elizabeth to James, [26 December 1598], CP, 133/180.

George Nicolson to Sir Robert Cecil, 2 February 1598/9, TNA, SP 52/64, fol. 16.

Sir James Elphinstone to Sir Robert Cecil, 28 February 1598/9, TNA, SP 52/64, 
continue to occupy a place in the diplomatic exchange and indeed in the royal correspondence.

Around the same time as the Anglo-Scottish diplomatic apparatus was turning its attention away from the Valentine Thomas affair, James wrote what would be his fourth and longest letter to Elizabeth on the issue. The letter is undated, but was thought by John Bruce to have been written early in 1599.52 Bruce's assessment matches the diplomatic context of the period, as the letter refers to the three abovementioned documents that accompanied Foulis's return to Scotland, and it preceded Elizabeth's appointment of an ambassador at the end of April 1599. Most likely James's letter was composed sometime between the end of February and early April 1599, but it is difficult to date it more precisely based upon the known evidence. In it, James stridently stated his dissatisfaction at how Elizabeth had managed the affair and the imputation to his honour. He argued that with the declaration 'the narration tharin decleres it to be onlie obteained by importunitie, $\&$ the conclusion thairof to be rather than an allowance of youre owin goode concepite that it hath pleased you to take of me than any aknouledge[ment] of my many goode \& honorable deserts at youre hande' ${ }^{53}$ He restated his desire that his name be removed from all documents relating to Thomas - an unnecessary action considering there were few documents relating to the whole situation, as had been, indicated to Foulis - and that a more appropriate declaration than the one provided be published. In his conclusion of his missive, James argued:

since the grounde of my requeste is onlie that ye wold helpe, not to cleare me of this false \& filthie calumnie, but onlie to declaire me to be the thing I ame indeed, vouchsafe then by some honorable means to give me onlie that quhiche I my self doe fullie possess, persuading so the worlde to beleave that quhiche in youre own conscience and knouledge ye are surelie persuaded of..$^{54}$

For James the matter of his innocence in the affair could still be regarded as questionable, and for that reason he ordered the return of the documents that he judged to be insufficient to his needs and wrote this firm missive to Elizabeth in his own hand.

Elizabeth, upon receiving James's letter and the reports from Scotland, decided not to reply through the correspondence she shared with James but rather to send an ambassador to Scotland in the hopes of finally bringing the affair to a conclusion. Sir William Bowes was her chosen ambassador, and she sent him a lengthy letter outlining the affair and stating she had 'lately received letters complaining himself of lack of sufficient clearing in the matter of Valentyne

52 John Bruce, Letters of Queen Elizabeth and King James VI of Scotland: Some of them printed from originals in the possession of the Rev. Edward Ryder, and others from a MS which formerly belonged to Sir Peter Thompson, KT., Camden Society, 46 (London: Nichols, 1849), p. 128.

53 James to Elizabeth, early 1599, CP, 133/140.

54 James to Elizabeth, early 1599, CP, 133/140. 
Thomas, who has accused him of some things we take no pleasure to make repetition'. ${ }^{55}$ Elizabeth instructed Bowes to 'Seek therefore by [speech with] him to discover whether it be some chang[e of some] clause that may content him or [whether he] stands still upon those terms that [Foulis did] propound, to which we mean by no [means to be] reduced]' ${ }^{56}$ Bowes travelled to Scotland, and during a number of audiences with James in late May he sought to clarify the situation and to resolve it. During one audience it became clear that James had been operating on the false premise that Thomas had already been tried in the courts, a mistaken understanding that required Bowes to explain the English legal process as it related to capital cases. ${ }^{57}$ Furthermore, he informed James that Elizabeth 'had restrained the greatest stroke of justice in your kingdom in a cause of highest quality, only in respect of him'. ${ }^{58}$ Bowes was ultimately able to convince James that Elizabeth's threefold actions on the Thomas affair - those being the suppression of Thomas's confession, her statement of his innocence in both her letter and public declaration, and the halting of Thomas's trial-were performed earnestly in the attempt to satisfy his needs in response to the accusations. Following Bowes's successful embassy, the issue of Valentine Thomas, which had dominated Anglo-Scottish diplomacy for roughly one year, fell into dormancy. But the question must be asked, why was it so significant in the first place?

\section{Why Valentine's Confession Became the Thomas Affair}

That the Valentine Thomas affair became a feature in Anglo-Scottish diplomacy for about one year is clear. However, the reason why the confession of a minor criminal such as Thomas would have such an effect is not so obvious at first glance, nor why the governments of England and Scotland took such divergent approaches to managing the situation. For England, and their queen, the less said or done about the affair the better. It was something that should be left to fade into obscurity to minimize any harm the false accusations could cause to James, a fact inherent in the English government's reluctance to inform James and only doing so after rumours had reached Scotland. Thomas's accusations were received very differently in Scotland, and by its king, where the Scots argued that the accusations needed to be dealt with precisely with no margin for error. The Scottish recommendations were highly contradictory, which made it difficult for the English to satisfy them. On the one hand the Scots demanded secrecy through the removal of any reference to James from the documents relating to Thomas, and on the other hand they requested public declarations of James's innocence regarding

55 Queen Elizabeth to Sir William Bowes, 25 April 1599, in Calendar of the State Papers Relating to Scotland and Mary, Queen of Scots, XIII, part 1, ed. by J. D. Mackie (Edinburgh: Her Majesty's Stationery Office, 1969) (hereafter CSPScots 13.1), p. 455.

56 Queen Elizabeth to Sir William Bowes, 25 April 1599, CSPScots 13.1, p. 460.

57 Sir William Bowes to Queen Elizabeth, 31 May 1599, BL, Cotton MS Caligula D II, fol. 382 .

58 Sir William Bowes to Queen Elizabeth, 31 May 1599, BL, Cotton MS Caligula D II, fol. 381 . 
the accusation. If the public declaration was made according the Scottish requests, Valentine Thomas's accusations against James would have also been made public, which would have removed the protection offered by secrecy in dealing with those false allegations. The reality is that both the English and the Scots were concerned over the same issue as a result of Thomas's accusations; but they held profoundly different understandings of the issue and how to manage the risks inherent in Thomas's confession. That issue being the succession to the English throne.

As Elizabeth was an unmarried woman with no children, she was to be the last monarch of the Tudor dynasty. This made the question of who should succeed her vitally important, both within England and internationally. Her lack of direct heirs led the debate over the succession to focus upon two main collateral lines, those of the Suffolks and the Stuarts, both of which descended from Henry VII. The Stuart line was the elder of the two, as it originated from Henry VII's eldest daughter Margaret, and of this line James VI was the strongest claimant. ${ }^{59}$ The Suffolks were the younger line, as they traced their descent to Mary Tudor, Henry VII's younger daughter. Furthermore, the Suffolk line was thoroughly tainted with questions of clandestine marriages and illegitimacy. Nevertheless, several members of it rose to importance during the lengthy debate over the succession, such as the sons of Catherine Grey_Edward, Lord Beauchamp, and Thomas Seymour — and the sons of Margaret and Henry Stanley, Lord Strange, Ferdinando and William Stanley. ${ }^{60}$ In addition to these two main lines of descent there were a number of other potential successors, though with often rather tenuous chances of succeeding, such as Henry Hastings, Earl of Huntington, and the Infanta Isabella Clara Eugenia of Spain. ${ }^{61}$ It would appear that the solution was relatively clear cut, with James the obvious successor, being legitimately descended from the elder line, a Protestant and male. However, when it came to the English succession there was nothing clear about who should succeed a childless monarch.

In a hereditary monarchy it would be presumed that the closest blood descendant would succeed to the throne. However, in England there was no established rule or law to govern the royal succession. ${ }^{62}$ Instead of a fixed law, during Elizabeth's reign there was a tangled web of parliamentary statute, a royal will and the precedents of English common law, all of which could influence the succession. Henry VIII's complicated marital history led to confusion over the succession, as he had three children from three wives. The solution initially

59 Mortimer Levine, The Early Elizabethan Succession Question 1558-1568 (Stanford: Stanford University Press, 1966), pp. 8-9.

60 Levine, The Early Elizabethan Succession Question, pp. 15-16, 210-11.

61 Susan Doran and Paulina Kewes, 'Introduction: A Historiographical Perspective', in Doubtful and Dangerous, ed. by Doran and Kewes, pp. 3-19 (p. 4).

62 Howard Nenner, The Right to be King: The Succession to the Crown of England, 1603-1714 (London: Macmillan, 1995), p. 7; Jean-Christophe Mayer, 'Introduction', in Breaking the Silence on the Succession: A Sourcebook of Manuscripts \& Rare Elizabethan Texts (c. 15871603), ed. by Jean-Christophe Mayer (Montpellier: Université Paul-Valéry Montpellier 3, 2003), p. 4. 
was the creation of a series of Succession Acts in Parliament, passed in 1534, 1536, and 1544, to clarify the order of succession. These Acts each reflect the concerns of Henry at the time of their construction, initially removing his daughter Mary from the succession to be replaced by Elizabeth, before removing Elizabeth as well, and finally in the 1544 Act returning both his daughters to the line of succession after his son Edward. ${ }^{63}$ Henry VIII was apparently not satisfied that the succession would occur as he intended, and so he sought to settle the matter in his will, a right given to him by the 1536 and 1544 Succession Acts. Approximately sixty per cent of Henry's will was concerned with the succession. ${ }^{64}$ While there is a sizeable debate concerning its authenticity, both in the sixteenth-century succession tracts and in modern scholarship, it was considered an important element in the discussion of the succession, as Henry called for the succession to bypass the Stuart claim in favour of the Suffolks. ${ }^{65}$ Finally, the succession was further complicated by English common law and the question of whether it applied to the crown. Common law was a significant impediment to the Stuart claim, as one of its maxims held that those born outside of the realm could not inherit. ${ }^{66}$ The issue of common law led to complicated debates over whether the maxim should apply to the crown, if Scotland was within the allegiance of the English crown based upon historic claims of overlordship, and an exemption to those of the royal blood based upon De natis ultra mare, a statute from the reign of Edward III. ${ }^{67}$

The tangled web of Henry VIII's will, parliamentary Acts and common law formed the basis of any consideration of the succession during Elizabeth's reign

6325 Hen. VIII c. 22, Parliamentary Archives (hereafter PA), HL/PO/ PU/1/1533/25H8n22; 28 Hen. VIII c. 7, PA, HL/PO/PU/1/1536/28H8n7; 35 Henry VIII, c. 1, PA, HL/PO/PU/1/1543/35H8n1 Public Act.

64 Suzannah Lipscomb, The King is Dead: The Last Will and Testament of Henry VIII (London: Head of Zeus, 2018), p. 107.

65 John Colville, The palinod of Iohn Coluill wherein he doth penitently recant his former proud offences, specially that treasonable discourse lately made by him against the vndoubted and indeniable title of his dread soueraigne Lord, King Iames the sixt, vnto the crowne of England, after decease of her Maiesty present (Edinburgh, 1600), p. 13; John Leslie, A defence of the honour of the right highe, mightye and noble Princesse Marie Quene of Scotlande and dowager of France with a declaration aswell of her right, title \& intereste to the succession of the crowne of Englande (London, 1569), p. 87; Irenicus Philodikaios, A treatise declaring, and confirming against all obiections the just title and right of the moste excellent and worthie prince, Iames the sixt, King of Scotland, to the succession of the croun of England (Edinburgh, 1599), p. 6; David Starkey, The Reign of Henry VIII: Personalities and Politics (London: Vintage, 2002), pp. 137-44; John Guy, Tudor England (Oxford: Oxford University Press, 1990), pp. 19899; E. W. Ives, 'Henry VIII's Will-A Forensic Conundrum', Historical Journal, 35.4 (1992), 779-804 (p. 797); R. A. Houlbrooke, 'Henry VIII's Wills: A Comment', Historical Journal, 37.4 (1994), 899-91 (p. 891); Lipscomb, The King is Dead, p. 64.

66 Marie Axton, The Queen's Two Bodies: Drama and the Elizabethan Succession (London: Royal Historical Society, 1977), p. 24.

67 Christopher W. Brooks, Law, Politics and Society in Early Modern England (Cambridge: Cambridge University Press, 2009), p. 74; Leslie, A defence of the honour, p. 57; 25 Edw. III, 'A Statute for Those Who Are Born in Parts beyond Sea', 1350-1351, in Statutes of the Realm, 11 vols (London: Record Commission, 1810-1828; repr. London: Dawsons of Pall Mall, 1963), I, 310. 
and each element was explored in relation to its impact upon the various claimants to the throne, as was the case with James VI. James's claim descended from Margaret Tudor, the eldest daughter of Henry VII, who had married James IV of Scotland. Together they had one son, James V, who would marry Mary of Guise and produce a single legitimate daughter, Mary Stuart, also known as the Queen of Scots. Following the death of Mary Stuart's first husband, King Francis II of France, she returned to Scotland and married Henry Stuart, Lord Darnley, who held his own claim to the English throne from his mother Margaret Douglas, countess of Lennox, who was the daughter of Margaret Tudor from her second marriage to Archibald Douglas, the Earl of Angus. ${ }^{68}$ The marriage of Mary Stuart and Henry Lord Darnley merged the two Stuart lines and provided their son King James VI of Scotland a strong hereditary right to the English throne, but as we have seen, blood descent was not a fixed rule for the succession. The Succession Acts themselves had little direct bearing upon James's claim. However, Henry VIII's will, which was provided for by the Acts, did. Henry's will called for the bypassing of the Stuart line, which was considered a significant impediment to James's claim should the will be upheld, and this triggered numerous debates in the succession tracts concerning the will's validity. ${ }^{69}$ The additional concern of the common law impediment against foreign inheritance was seen to be a significant challenge at the time..$^{70}$

The debates and challenges to James's right to the English throne were in no way settled by the 1590 s, but he generally appeared to be relatively convinced by his chances of succeeding Elizabeth. However, the publication in 1594 of A Conference about the Next Succession to the Crowne of Ingland by Robert Persons, a leader of the English Jesuits, appears to have triggered in James a heightened level of concern, and a sensitivity to any threat to his claim. In response to this tract James sent a complete outline of his right to the English throne to King Christian IV of Denmark, the dukes of Saxony, Brunswick, Schleswig-Holstein, and Meklenburg, the elector of Brandenburg, and the landgrave of Hess, to gather foreign support. ${ }^{71}$ It also prompted him in November 1596 to register in the Scottish Privy Council registers a letter by Elizabeth from 1586, which promised never to hinder his claim to the English throne. ${ }^{72}$ Persons's tract was not the first to question James's right to the succession, nor did it present any significantly new

68 Andy King and Claire Etty, England and Scotland, 1286-1603 (London: Palgrave, 2016), p. 95; Levine, The Early Elizabethan Succession Question, pp. 8-9.

69 Henry VIII's Will, TNA, E 23/4; Colville, The palinod, p. 13; Leslie, A defence of the honour, p. 87; Philodikaios, $A$ treatise, p. 6.

70 Leslie, A defence of the honour, pp. 57-59; Colville, The palinod, p. 9; John Harington, A Tract on the Succession to the Crown (A.D. 1602), ed. Clements R. Markham (London: Nichols, 1880), p. 61.

71 Doran, 'Revenge her Foul and Most Unnatural Murder?', p. 611.

72 Pauline Croft, King James (New York: Palgrave Macmillan, 2003), p. 22; Stafford, James VI of Scotland and the Throne of England, p. 190. 
information. ${ }^{73}$ However, its strong legal argument reminded those who read it of the various impediments to James's claim, impediments that could prevent him from ever becoming king of England.

The final strand of this tangled legal web that related to the Elizabethan succession, and the main source of James's anxiety concerning the Valentine Thomas affair, was the Act for the Queen's Safety. The Act had an interesting history, rising out of the 1584 Bond of Association created by William Cecil, Lord Burghley, and Sir Francis Walsingham. ${ }^{74}$ The Bond was an oath that circulated around England calling upon those who swore it to pursue any who tried to harm Elizabeth, and 'never to allow, accept, or favour any such pretended successors, by whom or for whom any such detestable act shall be attempted or committed'.75 The Bond was in effect advocating a lynch law mentality and was largely aimed against Mary Stuart, then held under arrest in England; but it also would have prevented the succession of James should Mary be found guilty of plotting against Elizabeth. ${ }^{76}$ Needless to say, Elizabeth was unimpressed with the overreach of her subjects, and when the Bond came to be reshaped into a parliamentary Act in 1585 the heir of any conspirator was protected, as long as they were not involved in the conspiracy themselves, a protection that was helpful following Mary Stuart's downfall only a year later. ${ }^{77}$ The Bond of Association and the Act for the Queen's Safety were two discrete documents. Nevertheless, they were often mistaken to be a single law, or in the case of Persons's tract, deliberately conflated. ${ }^{78}$ The distinction between the two was apparently not widely understood in Scotland, with Elphinstone, the Scottish Secretary of State, directing Foulis in his instructions to investigate what he termed the 'Act of Association', a clear conflation of the Bond and the Act, and that Foulis should 'get an authentick copie of the said Act that it may be advised wherein it may be hurtfull to his ma[jes] tie'. ${ }^{79}$ The Bond of Association raised the spectre of lynch law in the question of

73 Doran, 'James VI and the English Succession', pp. 29-31; R. Doleman [Robert Persons], A Conference abovt the Next Svccession to the Crowne of Ingland ([Antwerp], 1594).

74 David Cressy, 'Binding the Nation: The Bonds of Association, 1584 and 1696', in Tudor Rule and Revolution: Essays for G. R. Elton from his American Friends, ed. by Delloyd J. Guth and John W. McKenna (Cambridge: Cambridge University Press, 1982), pp. 217-34 (p. 218); Penry Williams, The Later Tudors: England 1547-1603 (Oxford: Oxford University Press, 1995), p. 301.

75 'The Bond of Association, 1584', in English Historical Documents, 10 vols in 12 (1953-2011), v (A): 1558-1603, ed. by Ian W. Archer and F. Douglas Price (London: Routledge, 2011), p. 961.

76 John Guy, My Heart is my Own: The Life of Mary Queen of Scots (London: Fourth Estate, 2004), pp. 474-75.

7727 Eliz. I c. 1, 'An Act for Provision to be made for the Suertie of the Queenes Majesties most Royall Person, and the continuaunce of the Realme in Peace', in Statutes of the Realm, IV.1, 705.

78 Doleman [Persons], A Conference, p. 117.

79 James Elphinstone to [David Foulis], 26 September 1598, TNA, SP 52/63, fol. 17. 
succession, a spectre that was thought to have been laid to rest by the Act of the Queen's Safety but rose again in the shadow of Thomas's confession.

James's thoughts regarding the succession were thrown into complete turmoil as a result of Thomas's accusations. He was already on edge after Persons's tract, which had pointed out, through a faulty conflation of the Bond of Association and the Act for the Queen's Safety, the risk to his claim should he be identified as being involved in any plot against Elizabeth. ${ }^{80}$ The capture and confession of Thomas four years later appeared to him to carry with it the potential to validate Persons's argument and bar him from the English throne. The key aspect of the Act that had James concerned stated that 'all Persons, against whome such Sentence or Judgement shall be so given and published, shall be excluded and dishabled for ever to have or clame, or to pretende to have or clame, the Crowne of this Realme'. ${ }^{81}$ James was concerned that the same mechanisms found within the Act that brought Mary, Queen of Scots, to trial-a woman still considered as a foreign monarch - could be used against him to remove his claim to the succession. It was for this reason that he urged such contradictory actions for the handling of the Valentine Thomas affair, and why he was exceedingly precise in the way it should be managed. James's demand for secrecy, that his name appears in no documentation concerning Thomas's confessed plot to kill Elizabeth, was based upon this Act. He feared that should Thomas's trial proceed with his name present he could have been considered a co-conspirator and thus removed from the succession. Likewise, James's demand for a public statement of his innocence was for a similar reason, so that the people of England could know he was not involved in any plot and thus could still succeed. James's concerns for the implications of Act of the Queen's Safety led to the minor issue of Valentine Thomas becoming a significant diplomatic affair in Anglo-Scottish diplomacy; however, he was not alone in his concerns, though they were approached in a significantly different manner by Elizabeth and her government.

Finally, James's response to Valentine Thomas's accusations was based not only upon the risks to his claim on the English throne, but also upon the implications for his honour. Throughout his letters that discussed the ongoing concern of the Valentine Thomas affair, the issue of his honour appears continuously. For early modern men, honour was preserved primarily by keeping their word and through demonstrations of strength in battle. ${ }^{82}$ In times of peace, honour for men was usually displayed by self-assertiveness, maintaining one's word, and being held in high-esteem by the public. ${ }^{83}$ As John Cleland, an early seventeenth-century writer, put it, honour 'is not in his hand who is honoured,

80 Doleman [Persons], A Conference, p. 117.

8127 Eliz. I c. 1, PA, HL/PO/PU/1/1584/27Eliz1n1.

82 Carol Levine, The Heart and Stomach of a King: Elizabeth I and the Politics of Sex and Power, 2nd edn (Philadelphia: University of Pennsylvania Press, 2013), p. 76.

83 Mervyn James, English Politics and the Concept of Honour 1485-1642 (Oxford: Past and Present Society, 1978), pp. 4, 7-8. 
but in the hearts and opinion of other men, who either haue seene his merits, or heard of his renowne, and good reputation'. ${ }^{84}$ In the context of Valentine Thomas's accusations, James argued that his honour had been impacted, as it presented him as a fellow conspirer to Elizabeth's assassination, which if true would have made him guilty of seeking the death of his godmother and kinswoman, whom he had pledged to support. However, while it is important to note that honour was a frequent topic within these letters, that is not to say that James's primary concern in the situation was his honour. Honour and the maintenance of it was a constant thread throughout the correspondence exchanged between Elizabeth and James over its thirty-one year history. ${ }^{85}$ Indeed, honour had previously been utilized by James in his final letter to Elizabeth before Mary, Queen of Scots's execution in early 1587 , as by transforming a political issue into one driven by honour made it more difficult for the accompanying request to be denied. ${ }^{86}$ James attempted to again transform a matter of necessity within the English political context into a matter of honour in order to force Elizabeth's hand. But, as was constant within the ongoing issue of the Valentine Thomas affair, to satisfy James's appeals to honour the accusations would be made highly visible and likely stir the English people against his succession, regardless of how false those accusations were.

Elizabeth was highly sensitive to the political climate within England, particularly regarding the long-standing issue of the succession. While it is difficult to pinpoint something as intangible as public mood, the anxiety of the English political class did find an outlet for expression in Parliament. Out of the thirteen sessions of Parliament held during Elizabeth's reign, the succession was debated, petitioned for, or legislated in eight. ${ }^{87}$ While the most recent Parliament had no debate concerning the succession, the one preceding it, which sat from 19 February to 10 April 1593, did. On 24 February Peter Wentworth and Sir Henry Bromley, both members of the Commons, delivered a petition to the Lord Keeper asking for the Lords to join with them in petitioning the Queen to settle the succession. ${ }^{8}$ The following day, after hearing of Elizabeth's displeasure that the succession was again being discussed in Parliament without her permission, Wentworth and his accomplices were incarcerated. ${ }^{89}$ It was in this context that Persons published

84 James Cleland, Hērō-paideia, or the Institution of a Young Noble Man (Oxford, 1607), p. 179.

85 Allinson, 'The Letters of Queen Elizabeth I and King James VI', p. 57; Rayne Allinson, 'Conversations on Kingship: The Letters of Queen Elizabeth I and King James VI', in The Rituals and Rhetoric of Queenship: Medieval to Early Modern, ed. by Liz Oakley-Brown and Louise J. Wilkinson (Dublin: Four Courts, 2009), pp. 131-44 (p. 143).

86 Doran, 'Revenge her Foul and Most Unnatural Murder?', p. 595; Tunstall, 'Of Honour and Innocence', pp. 62-63; James to Elizabeth, 26 January 1587, BL, Cotton MS Caligula C IX, fols 192-93.

87 Sir Simonds D'Ewes, The Journals of all the Parliaments during the Reign of Queen Elizabeth, both in the House of Lords and the House of Commons, ed. by Paul Bowes (London, 1682).

88 D'Ewes, The Journals of all the Parliaments, p. 470.

89 D'Ewes, The Journals of all the Parliaments, p. 470. 
A Conference about the Next Succession to the Crowne of Ingland. The narrative which Persons constructed to carry his arguments on the succession concerned a meeting of friends and their shared concerns following the failure of Wentworth and Bromley in Parliament. ${ }^{90}$ While the narrative was fictional, it did reflect the ongoing anxiety over the succession and the concerns many of the English political class held regarding the possibility of a Scottish succession. It also argued, as a number of Parliamentary debates had, that the succession should be determined by Parliament, and as the history of those discussions can attest to, those debates were firmly against James's succession. ${ }^{91}$ Furthermore, in this period of the succession debate, from the defeat of the Armada in 1588 until 1595, James's claim was either ignored or attacked by Protestants in England. ${ }^{92}$ AntiStuart sentiment had also been a relatively common thread throughout the debate, reaching particular heights in regards to Mary Stuart's claim. ${ }^{93}$ Elizabeth was aware of this long running agitation in the English Parliament, and its tendency towards excluding James from the succession, which prompted her to restrict its debate within Parliament. ${ }^{94}$ James's determination to have his innocence in the Valentine Thomas affair publicly declared throughout the kingdom would have informed the English political class of the accusations which had up till then been kept quiet. The revelation that he had been implicated in another plot against Elizabeth, regardless of those accusations' validity, could have made members of any future Parliament agitate again to establish the succession, and likely try to exclude the Stuart line from the succession once and for all.

Elizabeth and her government in England approached the Valentine Thomas affair from the outset in a distinctly different manner from that of James. Elizabeth was highly reluctant to inform James of Thomas's accusation, and once her hand had been forced, she wished the situation to be managed discreetly. Indeed, in her letter to Bowes before she sent him to Scotland, she stated that upon hearing of Thomas's accusations she had sought to ensure that they remain secret to protect James. ${ }^{95}$ To Elizabeth, the matter should be kept as quiet as possible, for she was well aware of the risk the Act for the Queen's Safety posed to James's claim, and how damaging public knowledge of the accusations would be to his claim, regardless of their false nature. Elizabeth sought in her letters, and through the

90 M. J. M. Innes, 'Robert Persons, Popular Sovereignty, and the Late Elizabethan Succession Debate', Historical Journal, 62.1 (2019), 57-76 (p. 57).

91 Innes, 'Robert Persons', p. 68.

92 Paulina Kewes, 'The Puritan, the Jesuit and the Jacobean Succession', in Doubtful and Dangerous, ed. by Doran and Kewes, pp. 47-70 (p. 65).

93 Mortimer Levine, Tudor Dynastic Problems 1460-1571 (London: Allen \& Unwin, 1973), p. 106.

94 J. E. Neale, 'The Commons' Privilege of Free Speech in Parliament', in Tudor Studies: Presented by the Board of Studies in History in the University of London to Albert Frederick Pollard, ed. by R. E. Seton-Watson (London: Longmans, Green, 1924), pp. 257-86 (p. 279); Michael A. R. Graves, Elizabethan Parliaments 1559-1601, 2nd edn (London: Longmans, 1996), p. 49.

95 Queen Elizabeth to Sir William Bowes, 25 April 1599, CSPScots 13.1, p. 456. 
eventual granting of the declaration against Thomas, to disarm the potentially volatile situation. For this reason, Elizabeth sought to allow the accusations to fade away from peoples' minds, halting the proceedings against Thomas and keeping him imprisoned. It was ultimately the succession which drove her actions against Thomas, and her management of the affair, as unlike James she had a superior understanding of the English people, whom she had ruled for forty years, and how the public airing of the situation could undermine everything. James saw his position differently, as he viewed it through the prism of the Scottish political context and the execution of his mother, Mary Stuart, after her involvement in a plot had been uncovered. James's anxiety over the succession made him misread the English political situation and press for public declarations that would have placed him at direct risk of the very Act he had been trying to avoid, a situation Elizabeth and her Privy Council strove to protect him from.

\section{The Final Revival of the Thomas Affair, 1601}

Elizabeth's desire for the Valentine Thomas affair to fade appeared to occur following the embassy of Bowes to Scotland in May 1599, but it was revived again in early 1601 . The circumstances of its return to prominence were rather unusual, though very little concerning the affair was normal. Late 1600 and early 1601 saw the downfall of Robert Devereux, the Earl of Essex, who for at least three years served as James's main source of information on the English government. ${ }^{96}$ In a letter he sent to James, dated 25 December 1600, Essex asks that James send an embassy to London by 1 February 1601 to support him and to counter the manoeuvres of their shared enemies, most likely Sir Robert Cecil. ${ }^{97}$ James was cautious about openly supporting Essex and meeting the deadline the earl had set. However, by February 1601 George Nicolson, still serving as Elizabeth's agent in Scotland, reported that an embassy was being prepared. It was to consist of the Earl of Mar and the Abbot of Kinloss, but the purpose of the embassy was being keep secret, with Nicolson reporting:

The conjectures and conceiptes of this ambassage are exceding strange and many, yea w[it]h counsellors and wise men, and the wisest are at a gaize to se what may follow it. The reason is, it is so secret the Counsell beinge no way acquainted $w[i t] h$ the earandes or ground of. The Secretary, no secretary in this, but only the k[ing]. ${ }^{98}$

The delay in James's secretive embassy's departure meant that by the time it had arrived in London Essex's revolt had failed and the earl had been executed. ${ }^{99}$ Following Essex's death, the embassy's public mission was to congratulate

96 Croft, King James, p. 48.

97 Earl of Essex to King James VI, 25 December 1600, in Calendar of the State Papers Relating to Scotland and Mary, Queen of Scots, XIII, part 2, ed. by J. D. Mackie (Edinburgh: Her Majesty's Stationery Office, 1969), pp. 756-57.

98 George Nicolson to Sir Robert Cecil, 7 February 1600/1, TNA, SP 52/67, fol. 14.

99 Williams, The Later Tudors, p. 385. 
Elizabeth on her survival from the plot against her and to discuss certain outstanding issues in Anglo-Scottish diplomacy, amongst which was the matter of Valentine Thomas.

The first indication that the Valentine Thomas affair was to be revived is found within a letter from Nicolson to Cecil, dated 14 February. He wrote that while the embassy shortly to depart Scotland was cloaked in secrecy, he did 'perceive that they are to have the league in question, Valentyne Thomas matter, Sir William Eure and the rest' ${ }^{100}$ His perception proved to be accurate, and by April the affair had returned fully. According to Cecil, the Scottish ambassadors in their audiences with Elizabeth argued that James

insisted much uppon the matter of Valentyne Thomas pretendinge that he is jealous in that matter lest he be keept in store to accuse him, and so uppon such an accusation to make hereafter some application to his preiudice because there is a statute in England w[hi]ch defaults all persons from succession that shall be proved to have conspired any such matter as that knave is accused of. In these p[ar]ticuler things her $\mathrm{ma}$ [jes]ty and my Lords aforenamed have interchanged many words they thinkinge by argument to $\mathrm{p}[\mathrm{er}]$ suade her whose nature you know to be more unapt to yield even in trifles when she concieveth they are challenged as dutyes then in greate matters. ${ }^{101}$

Cecil's analysis of the situation proved to be correct, and Elizabeth refused to provide any further satisfaction on the affair or to reopen the issue. Indeed, she took the situation into her own hands and sought to finally put the whole affair to rest.

Dated 11 May 1601, Elizabeth's lengthy letter is firmly worded, leaving little doubt about her irritation that issues such as the Valentine Thomas affair had again been raised by James. In her letter she addressed the affair directly, naming Thomas for the first time in her letters on the subject. She wrote:

For first, to the matter of Valentine Thomas. Wee have often saide the same w[hi]ch wee have nowe made plaine unto them, that whatsoever hath ben forborne to be done against him hath ben meerely done by us in your favour, because wee would not stir a new that matter w[hi]ch nowe lyeth deade, and connot be revived w[it]hout some scandall howe unjust soever. Next, wee must still saye, that what your owne ministers wishe nowe to be done therein, for your further satisfaction, hath ben already done in effect to your servant Fowles at his last departure. ${ }^{102}$

Elizabeth's letter continued by stating 'wee hope to heare no more of any of these matters, w[hi]ch are so unworthie of our dispute', and adding that 'nothing more disgraced then when our comon adversaryes shall see, that when noe newe causes can be founde, olde and by past scruples are revived' ${ }^{103}$ In her letter, the final one

100 George Nicolson to Sir Robert Cecil, 14 February 1600/1, TNA, SP 52/67, fol. 27.

101 Sir Robert Cecil to the Master of Gray, April 1601, TNA, SP 52/67, fol. 92.

102 Elizabeth to James, 11 May 1601, BL, Sloane MS 1786, fol. 53v.

103 Elizabeth to James, 11 May 1601, BL, Sloane MS 1786, fol. 55. 
to discuss the affair, Elizabeth was clear that she would humour James no longer in his obsession over Thomas, as it would be more risky to revive it than to let it slumber. And following Elizabeth's letter slumber it did. For the remainder of her life the Valentine Thomas affair remained dormant, with only one final act left in the drama to unfold after her death.

Elizabeth I, Queen of England, died early in the morning on 24 March 1603. She was succeeded by James VI, King of Scotland, in a remarkably smooth transition considering the anxiety and debate that had occurred in the forty-five years preceding it. Amongst the celebrations of James's peaceful accession and the movement of the new English king from his original kingdom of Scotland to England, the unlikely matter of Valentine Thomas briefly appeared one final time. As a later writer would record,

But that King kept a severe memory of the accusation cast upon him by Valentine Thomas; and, upon his accession the Crown of England, and within a month after his arrival in London, in the beginning of June 1603. ordered him to be brought to is tryal, and executed. ${ }^{104}$

Thus, the Valentine Thomas affair definitively ended, the unlikely story of an insignificant thief's confession becoming a significant complication in AngloScottish diplomacy on and off again for a period of five years.

The Valentine Thomas affair was significant because of the implications of Thomas's confession on the English succession. From the outset the affair was seen through a lens that considered its potential repercussions to James's claim on the English throne. While the reason for its significance was mutually understood by both Elizabeth and James, as well as their respective governments, they came to vastly different conclusions as to the way in which it should be managed. For Elizabeth, whose view was supported by her government, the accusations should remain as secret as possible lest it implicate James and risk him falling under the terms of the Act for the Queen's Safety, which had provided the mechanisms for Mary Stuart's execution. Whereas for James, and his government in Scotland, in addition to the removal of his name from Thomas's confession the matter needed nothing less than a full public declaration of his absolute innocence in the affair or his future claim might be suspect. James's position, while understandable in the political climate of Scotland, was highly problematic in the tense political context of England, which had been ferociously debating the succession for the entirety of Elizabeth's reign. In the end, Elizabeth's perception of the affair proved to be the wiser course, as letting it fade from sight allowed even the rumours of James's involvement in a plot against her to die, leaving his path clear in 1603 to succeed as England's king.

The University of Melbourne

104 Thomas Birch, An Historical View of the Negotiations between the Courts of England, France, and Brussels: From the Year 1592 to 1617 (London, 1749), p. 179. 



\section{University Library}

\section{- M M N E R VA A gateway to Melbourne's research publications}

Minerva Access is the Institutional Repository of The University of Melbourne

Author/s:

Tunstall, E

Title:

The Paradox of the Valentine Thomas Affair: English Diplomacy, Royal Correspondence and the Elizabethan Succession

Date:

2021

Citation:

Tunstall, E. (2021). The Paradox of the Valentine Thomas Affair: English Diplomacy, Royal Correspondence and the Elizabethan Succession. Parergon: Journal of the Australian and New Zealand Association for Medieval and Early Modern Studies, 38 (1), pp.65-87. https:// doi.org/10.1353/pgn.2021.0004.

Persistent Link:

http://hdl.handle.net/11343/279455 